\title{
Deskripsi Kemampuan Mahasiswa Biologi Tahun Ajaran 2009/2010 Dalam Penyusunan Rencana Pembelajaran Berdasarkan KTSP di Sekolah Menengah
}

\author{
Reni Marlina \\ Pendidikan Biologi, FKIP Universitas Tanjungpura
}

\begin{abstract}
Abstrak
Penelitian ini bertujuan untuk mengetahui deskripsi kemampuan mahasiswa program studi pendidikan Biologi jurusan P.MIPA FKIP UNTAN dalam menyusun rencana pembelajaran yang sesuai KTSP di sekolah menengah. Metode yang digunakan adalah penelitian deskriptif. Subjek penelitiannya adalah mahasiswa program studi pendidikan Biologi Kerjasama Pemerintah Daerah Kabupaten Ketapang dan Kabupaten Bengkayang Jurusan P.MIPA FKIP UNTAN angkatan 2009 yang berjumlah 32 orang. Teknik pengumpul data berupa pengamatan lapangan, wawancara dan dokumentasi sedangkan alat pengumpul data adalah lembar pengamatan tentang Rencana Pembelajaran yang sesuai KTSP dan dokumentasi. Berdasarkan hasil pengamatan dan dokumentasi hasil penyusunan rencana pembelajaran diperoleh rata-rata 74\% sesuai dengan KTSP.
\end{abstract}

Kata kunci : implementasi KTSP, rencana pelaksanaan pembelajaran, proses kegiatan pembelajaran

\section{Pendahuluan}

Penelitian ini adalah penelitian deskriptif yang diterapkan di program studi pendidikan Biologi jurusan pendidikan MIPA FKIP UNTAN pada mahasiswa kerjasama Pemda Ketapang dan Bengkayang. Beberapa hal yang melatarbelakangi masalah penelitian ini antara lain kesulitan para guru mengkonstruksi pembelajaran yang memperhatikan potensi dinamis para siswanya tetapi juga mempertimbangkan sarana dan prasarana yang tersedia yang memungkinkan terselenggaranya pembelajaran yang memperhatikan individu-individu tersebut.

Pembelajaran di sekolah menegah di Indonesia hingga saat ini umumnya masih dilakukan secara klasikal (umumnya satu kelas lebih dari 30 siswa), sebab pengajaran klasikal merupakan pengajaran yang paling efisien dari aspek tenaga, biaya maupun waktu pelaksanaannya. Bentuk pembelajaran ini mampu menghadapi sekelompok peserta didik dalam suatu kelas yang relatif besar jumlahnya dengan tindakan yang sama, baik dari cara penyajian, penyediaan bahan atau materi yang disajikan, waktu pelaksanaannya maupun setting penyelenggaraannya.

Pembelajaran klasikal memiliki kelemahan yaitu kurangnya perhatian bagi individu-individu yang memiliki kemampuan beragam. Dari hal di atas, sebagai calon guru (mahasiswa FKIP khususnya mahasiswa pendidikan Biologi) atau seorang 
guru seharusnya telah mempersiapkan perangkat pembelajaran yang memperhatikan potensi setiap siswanya. Atau paling tidak memiliki kompetensi dalam penyusunan perangkat pembelajaran yang sesuai.

Selain itu, permasalahan yang dihadapi guru dalam meningkatkan kualitas hasil belajar siswa, khususnya optimalisasi kemampuan individual siswa, maksimalisasi perolehan materi pelajaran, artinya kelompok siswa yang pandai atau kemampuannya diatas rata-rata yang jika diajar dengan lama waktu yang sama sebenarnya dapat menyerap lebih banyak materi dari pada siswa dalam kelompok kemampuan yang sedang atau kurang. Umumnya guru mengajarkan materi menyesuaikan dengan rata-rata kemampuan kelas atau semaunya guru, hal ini kadangkadang menyebabkan kelompok siswa yang berkemampuan dibawah rata-rata mengalami kesulitan menerima materi atau bahkan sama sekali tidak terserap, tetapi jika persediaan waktu lebih longgar atau siswa kelompok ini diajar lebih lambat barangkali persentase penyerapan dapat ditingkatkan sesuai dengan kemampuanya. Dengan adanya perangkat pembelajaran yang dipersiapkan sebelumnya, guru akan dapat meminimalisir permasalahan di atas.

Mahasiswa program studi pendidikan Biologi adalah calon guru, disamping kemampuan akademik yang memadai, memiliki kepribadian dengan ciri-ciri tertentu: percaya diri, antusias, menyukai hubungan interpersonal, empati, komunikator yang baik, pendengar yang baik, sabar, dan dedikasi, mereka dituntut pula memiliki kompetensi dalam menyusun perangkat pembelajaran sehingga dapat dipergunakan dalam proses pembelajaran jika kelak telah mengajar di sekolah. Pembuatan perangka pembelajaran ini barangkali tidak dapat langsung dikuasai dari salah satu mata kuliah yang hanya sekedar ceramah, menyelesaikan soal, tugas terstruktur, tugas mandiri saja. Dengan penelitian ini diharapkan mahasiswa dapat meningkatkan kompetensi dalam penyusunan perangkat pembelajaran di sekolah menengah. Dari uraian diatas muncul permasalahan secara umum antara lain tentang "Bagaimana deskripsi kemampuan mahasiswa dalam penyusunan perangkat pembelajaran di sekolah menengah"? Dengan tujuan untuk; menyusun perangkat pembelajaran yang akan digunakan di sekolah menengah, mengetahui deskripsi kemampuan mahasiswa dalam merancang strategi pembelajaran, mengetahui kemampuan mahasiswa dalam merancang umpan balik dan teknik evaluasi proses belajar dan menyesuaikan perangkat pembelajaran yang disusun oleh mahasiswa dengan KTSP.

Penelitian ini diharapkan dapat memberikan rmanfaat kepada: (1) mahasiswa, sehingga dapat meningkatkan kompetensi mereka dalam pembuatan perangkat pembelajaran di sekolah menengah, meningkatkan kualitas hasil belajar mereka, khususnya optimalisasi kemampuan individual, dan maksimalisasi pemahaman mereka pada mata kuliah telaah kurikulum serta mengkonstruksi pembelajaran yang memperhatikan potensi dinamis para mahasiswanya tetapi juga mempertimbangkan keberlanjutan 
mereka sebagai calon guru yang akan terjun ke lapangan sebagai guru yang diharapkan keprofesionalannya. Menurut Kunandar (2007) ada beberapa perbedaan antara kurikulum yang lama (sebelumnya) dengan KTSP yaitu:

\begin{tabular}{|c|c|c|}
\hline Aspek & $\begin{array}{c}\text { Kurikulum } \\
\text { lama }\end{array}$ & KTSP \\
\hline Siswa & Pasif & $\begin{array}{l}\text { Aktif-Kreatif- } \\
\text { Produktif }\end{array}$ \\
\hline Kurikulum & Subject & Competency \\
\hline Guru & Based & Based \\
\hline Sarana & Instruktif & Fasilitatif \\
\hline prasarana & Weaknessess & Adequate \\
\hline Pembelajaran & $\begin{array}{l}\text { Pasif } \\
\text { learning }\end{array}$ & Aktif learning \\
\hline Evaluasi & $\begin{array}{l}\text { Subject } \\
\text { oriented }\end{array}$ & Competency \\
\hline Manajemen & Sentralistik & Desentralistik \\
\hline $\begin{array}{l}\text { Supervisi dan } \\
\text { pengawasan }\end{array}$ & $\begin{array}{l}\text { Model } \\
\text { tagihan }\end{array}$ & $\begin{array}{l}\text { Model } \\
\text { bimbingan dan } \\
\text { pemberdayaan }\end{array}$ \\
\hline $\begin{array}{l}\text { Lingkungan } \\
\text { dan } \\
\text { masyarakat }\end{array}$ & $\begin{array}{l}\text { Cenderung } \\
\text { pasif }\end{array}$ & $\begin{array}{l}\text { Kondusif } \\
\text { (peduli) }\end{array}$ \\
\hline
\end{tabular}

Ket: Kurikulum lama (Kurikulum sebelum KTSP misalnya Kurikulum 1968, Kurikulum 1984, Kurikulum 1994 dan KBK)

\section{Metodologi Penelitian}

Penelitian ini bertujuan untuk mendeskripsikan kemampuan mahasiswa dalam menyusun rencana pembelajaran yang sesuai KTSP di sekolah menengah, maka metode penelitian yang digunakan adalah metode deskriptif. Dari hasil penelitian akan digambarkan deskripsi kemampuan mahasiswa dalam menyusun rencana pembelajaran yang meliputi perancangan strategi pembelajaran, merancang umpan balik dan teknik evaluasi proses belajar. Subjek dalam penelitian ini adalah mahasiswa program studi pendidikan Biologi jurusan Pendidikan MIPA FKIP
UNTAN yang berjumlah 32 orang. Mahasiswa yang terlibat dalam pengambilan data adalah berasal dari kerjasama Pemda Kabupaten Bengkayang dan Ketapang. Objek dalam penelitian ini adalah penyusunan rencana pembelajaran yang sesuai dengan KTSP di sekolah menegah.

Pada penelitian ini, peneliti menggunakan lembar pengamatan tentang Rencana Pembelajaran yang sesuai KTSP dan dokumentasi. Menurut Margono (2005) dokumentasi merupakan cara mengumpulkan data melalui peninggalan tertulis seperti arsip-arsip dan termasuk juga buku-buku tentang pendapat, teori, dalil, atau hukumhukum dan lain-lain yang berhubungan dengan masalah penelitian. Hal ini sejalan dengan pendapat Sugiyono (2007) dokumen merupakan catatan peristiwa yang sudah berlalu. Dokumen bisa berbentuk tulisan, gambar, atau karya-karya monumental seseorang. Dokumen yang berbentuk tulisan misalnya catatan harian, sejarah kehidupan, ceritera, biografi, peraturan dan kebijakan. Dokumen yang berbentuk gambar, misalnya foto, gambar hidup dan sketsa. Dokumentasi dalam penelitian ini bertujuan untuk mendapatkan informasi data berupa dokumen. Adapun dokumen yang digunakan dalam penelitian ini adalah rencana pembelajaran.

Prosedur yang dilakukan dalam penelitian ini adalah :

1. Tahap persiapan

a. Melakukan survey awal. Menggali kepustakaan, dalam hal ini mencari informasi mengenai pelaksanaan 
pembelajaran IPA-Biologi yang berdasarkan KTSP

b. Menentukan subjek dan objek penelitian

c. Pembuatan instrumen penelitian (lembar pengamatan dan dokumentasi)

2. Tahap pelaksanaan Mengambil data di lapangan

3. Pengolahan data

a. Mengumpulkan data melalui pengamatan dan dokumentasi.

b. Mengelompokkan dan mengidentifikasi data yang telah terkumpul. Data yang diperoleh dianalisa dengan cara persentase $(\%)$ kemudian diungkapkan dalam pernyataan-pernyataan yang dapat memberikan jawaban terhadap masalah yang diteliti.

c. Berdasarkan hasil pengolahan data tersebut, kemudian ditarik suatu kesimpulan dan disampaikan saran-saran.

4. Tahap pelaporan

Penskoran yang digunakan dalam instrumen penelitian ini menggunakan skala Guttman. Menurut Riduwan (2008) skala Guttman ialah skala yang digunakan untuk jawaban yang bersifat jelas (tegas) dan konsisten. Skala Guttman dapat dibuat dalam bentuk pilihan ganda dan bentuk checklist. Jawaban responden dengan skor tertinggi bernilai 1 dan skor terendah 0 . Pada penelitian ini digunakan bentuk checklist yang digunakan untuk penskoran pada lembar pengamatan rencana pembelajaran.

Analisis lembar pengamatan rencana pembelajaran dilakukan dengan cara menghitung persentase. Persentase skor per item $=(\mathrm{n} / \mathrm{p}) \times 100 \%$

$$
\begin{aligned}
& \mathrm{n}=\text { skor yang diperoleh } \\
& \mathrm{p}=\text { Jumlah skor dalam satu } \\
& \text { item }
\end{aligned}
$$

Menurut Riduwan (2008) skor instrumen penelitian memiliki kriteria interpretasi skor. Adapun kriteria skor dalam instrumen penelitian ini antara lain:

$$
\begin{aligned}
\text { Angka } 0 \%-20 \% & =\begin{array}{l}
\text { Sangat tidak } \\
\text { sesuai }
\end{array} \\
\text { Angka } 21 \%-40 \%= & \text { Tidak sesuai } \\
\text { Angka } 41 \%-60 \%= & \text { Cukup sesuai } \\
\text { Angka } 61 \%-80 \%= & \text { Sesuai } \\
\text { Angka } 81 \%-100 \%= & \text { Sangat } \\
& \text { sesuai. }
\end{aligned}
$$

\section{Hasil Penelitian dan Pembahasan Hasil Penelitian}

Berdasarkan hasil pengamatan dan dokumentasi hasil penyusunan rencana pembelajaran oleh mahasiswa pendidikan Biologi Kerjasama Pemda Ketapang dan Bengkayang, diperoleh hasil persentase (\%) yang disajikan data seperti pada tabel di bawah ini:

Tabel 1. Persentase Kesesuaian Hasil Pengamatan Rencana Pembelajaran

\begin{tabular}{|l|l|c|c|}
\hline \multirow{2}{*}{ No } & \multicolumn{1}{|c|}{$\begin{array}{c}\text { Pengamatan } \\
\text { Rencana } \\
\text { Pembelajaran }\end{array}$} & \multicolumn{2}{|c|}{$\begin{array}{c}\text { Persentase } \\
\text { (\%) }\end{array}$} \\
\cline { 3 - 4 } 1 & $\begin{array}{l}\text { Rencana } \\
\text { Pembelajaran } \\
\text { Kelompok I }\end{array}$ & 76 & TS \\
\hline 2 & $\begin{array}{l}\text { Rencana } \\
\text { Pembelajaran } \\
\text { Kelompok II }\end{array}$ & 76 & 24 \\
\hline 3 & $\begin{array}{l}\text { Rencana } \\
\text { Pembelajaran } \\
\text { Kelompok III }\end{array}$ & 73 & 27 \\
\hline 4 & $\begin{array}{l}\text { Rencana } \\
\text { Pembelajaran } \\
\text { Kelompok IV }\end{array}$ & 76 & 24 \\
\hline 5 & $\begin{array}{l}\text { Rencana } \\
\text { Pembelajaran } \\
\text { Kelompok V }\end{array}$ & 76 & 24 \\
\hline
\end{tabular}




\begin{tabular}{l|l|c|c|}
\hline 6 & $\begin{array}{l}\text { Rencana } \\
\text { Pembelajaran } \\
\text { Kelompok VI }\end{array}$ & 76 & 24 \\
\hline 7 & $\begin{array}{l}\text { Rencana } \\
\text { Pembelajaran } \\
\text { Kelompok VII }\end{array}$ & 66 & 34 \\
\hline & Rata-rata (\%) & 74 & 26 \\
\hline Ket: \\
S \\
TS & $\begin{array}{l}\text { : Sesuai dengan KTSP } \\
\text { : Tidak sesuai dengan KTSP }\end{array}$
\end{tabular}

Dari tabel di atas, diketahui pembelajaran adalah sebesar 74\% yang tergolong dalam kriteria sesuai.

\section{Pembahasan}

Berdasarkan

rencana pembelajaran yang telah disusun didapatkan informasi bahwa kelompok 1, kelompok 2, kelompok 4, kelompok 5 dan kelompok 6 mempunyai persentase kesesuaian dengan KTSP yang sama (76\%) sedangkan kelompok 3, 73\% dan kelompok 7 sebesar $66 \%$. Sedangkan rata-rata kesesuaian seluruh aspek yang dituliskan pada semua kelompok sebesar 74\%. Interpretasi kesesuaian ke tujuh kelompok dan rata-rata kesesuaian semua kelompok ini mempunyai kriteria sesuai KTSP. Adanya perbedaan persentase kesesuaian antara kelompok satu dengan kelompok lainnya disebabkan terdapatnya perbedaan kelengkapan aspek-aspek yang disusun pada setiap kelompok. Aspek-aspek sesuai KTSP yang telah dituliskan pada semua RPP antara lain:

1. Menuliskan kolom identitas

2. Menuliskan alokasi waktu pembelajaran

3. Menuliskan standar kompetensi

4. Menuliskan kompetensi yang akan dicapai

5. Menuliskan tujuan pembelajaran yang akan dicapai
6. Menentukan materi yang akan diajarkan

7. Menentukan model dan metode pembelajaran yang sesuai dengan materi yang akan diajarkan

8. Membuat rancangan skenario pembelajaran

9. Membuat rincian kegiatan pendahuluan

10. Melakukan apersepsi belajar kepada siswa

11. Memberikan motivasi belajar kepada siswa

12. Memuat rincian kegiatan inti

13. Menyajikan informasi pelajaran

14. Menumbuhkan partisipasi aktif siswa melalui interaksi guru, siswa dan sumber belajar

15. Menjabarkan model dan metode pembelajaran yang digunakan

16. Membuat rincian kegiatan penutup

17. Membimbing siswa untuk membuat kesimpulan dari materi yang diajarkan

18. Memberikan soal post-test (lisan/tulisan) yang sesuai dengan tujuan pembelajaran

19. Melaksanakan tindak lanjut dengan memberikan arahan, atau kegiatan, atau tugas sebagai bagian remedy/pengayaan

20. Menentukan sumber belajar yang sesuai dengan kurikulum

21. Alat bantu/media pembelajaran

22. Membuat rancangan penilaian

23. Menuliskan teknik penilaian

24. Menuliskan bentuk instrument

25. Membuat teknik penskoran

Rencana pembelajaran yang disusun oleh kelompok 3 ditemukan beberapa aspek yang tidak sesuai dengan KTSP antara lain tidak menuliskan metode dan model yang digunakan, mengucapkan salam, 
memberikan pre-test, memberikan kesempatan kepada siswa untuk bertanya, memberikan penguatan kepada siswa yang dapat menjawab pertanyaan guru dengan benar dan mengucapkan salam penutup pelajaran. Rencana pembelajaran yang telah disusun mengandung kalimat-kalimat yang tidak panjang, dan jika aspek-aspek tersebut dituliskan maka akan membuat kalimat pada rencana pembelajaran menjadi panjang dan rumit sehingga tidak efisien.

Begitu pula dengan rencana pembelajaran yang disusun oleh kelompok 7. Selain aspek-aspek di atas, ditemukan aspek-aspek yang tidak sesuai dengan KTSP yaitu tidak menuliskan kompetensi yang akan dicapai serta tidak menuliskan media pembelajaran yang digunakan. Sebaiknya dalam penyusunan rencana pembelajarancalon guru atau guru harus menuliskan aspek-aspek tersebut karena dengan dituliskan maka rencana pembelajaran terlihat lebih jelas dan memudahkan mempelajari skenario kegiatan pembelajarannya. Sehingga diharapkan pada kegiatan pembelajarannya akan menjadi efisien dan terarah.

Selain itu dari hasil pengamatan rencana pembelajaran yang disusun ditemukan informasi bahwa pada skenario kegiatan inti pembelajaran masih belum sistematis atau runtut sesuai dengan tujuan pembelajaran yang dituliskan. Seharusnya antara tujuan pembelajaran dan skenario kegiatan inti pembelajaran saling berkesinambungan sehingga diharapkan pembelajaran yang dilakukan lebih sistematis atau runtut. Pada rencan pembelajaran dituliskan alat bantu pembelajaran berupa LKS. Tetapi LKS tersebut tidak dilampirkan. Sebaiknya dalam rencana pembelajaran harus melampirkan LKS yang digunakan. Hal ini bertujuan agar pelaksanaan kegiatan pembelajaran lebih mudah dilakukan. Disamping itu juga dengan adanya LKS kegiatan pembelajaran siswa menjadi lebih aktif dan metode pembelajaran menjadi bervariasi.

Pada seluruh rencana pembelajaran yang disusun oleh seluruh kelompok mahasiswa kerjasama pemda kabupaten bengkayang dan ketapang FKIP UNTAN tertulis SK, KD dan indikator beracuan pada silabus yang diberikan. Sebagian besar model yang dipilih adalah model pembelajaran kooperatif dengan alasan agar siswa terlibat aktif dalam pembelajaran. Disamping itu sebaiknya dalam membuat soal evaluasi harus menyesuaikan tujuan pembelajaran yang ada. Tetapi pada pelaksanaannya rencana pembelajaran yang disusun tidak membuat instrumen penilaian yang sesuai dengan tujuan pembelajaran. Instrumen penilaian yang dituliskan di rencana pembelajaran jumlahnya sedikit dan belum mencakup semua tujuan pembelajaran. Sebaiknya dalam pembuatan instrumen penilaian, guru harus menyesuaikan dengan tujuan pembelajaran yang telah tertulis. Hal ini bertujuan agar kompetensi pembelajaran yang diharapkan dapat tercapai.

\section{Simpulan dan Saran \\ Simpulan}

Berdasarkan hasil pengamatan dan dokumentasi dari hasil penyusunan rencana pembelajaran 
oleh mahasiswa pendidikan Biologi FKIP UNTAN didapatkan kesimpulan bahwa:

1. Kemampuan rata-rata mahasiswa dalam merancang strategi pembelajaran adalah sebesar $74 \%$.

2. Kemampuan rata-rata mahasiswa dalam merancang strategi pembelajaran tergolong sesuai dengan kategori KTSP.

\section{Saran}

Saran yang perlu peneliti sampaikan berdasarkan hasil penelitian ini adalah sebagai berikut: sebaiknya calon guru atau mahasiswa FKIP khususnya program studi pendidikan Biologi menggunakan rencana pembelajaran yang dibuat sendiri, kepada calon guru IPABiologi dan guru IPA-Biologi hendaknya dapat mengimplementasikan KTSP dalam pelaksanaan pembelajaran, dalam menyusun rencana pembelajaran, sebaiknya calon guru atau guru mengikuti format berdasarkan KTSP dan sebaiknya dalam rencana pembelajaran yang dibuat guru harus melampirkan LKS yang dibuat sendiri. Hal ini bertujuan agar pelaksanaan kegiatan pembelajaran lebih mudah dilakukan. Karena dengan adanya LKS biasanya siswa lebih aktif belajar

\section{Daftar Pustaka}

Badan Standar Nasional Pendidikan (BSNP). 2006. Panduan Penyusunan Kurikulum Tingkat
Satuan Pendidikan Jenjang Pendidikan Dasar dan Menengah. Jakarta : BSNP.

Beni, Damaskus. 2009. Persamaan dan Perbedaan KBK dengan KTSP. Jurnal dalam http://sungebanjur.blogspot.com 12009/06/persamaan-danperbedaan kbk dan ktsp.html. (Diakses tanggal 1 Juli 2009).

Kunandar. 2007. Guru Profesional (Implementasi Kurikulum Tingkat Satuan Pendidikan dan Sukses dalam Sertifikasi guru). Jakarta : Rajawali Pers.

Margono. 2005. Metode Penelitian Pendidikan. Jakarta : Rineka Cipta.

Mulyasa, Edy. 2008. Kurikulum Tingkat Satuan Pendidikan. Bandung : Remaja Rosdakarya.

Muhaimin. 2008. Pengembangan Model Kurikulum Tingkat Satuan Pendidikan (KTSP) pada Sekolah dan Madrasah. Jakarta : Raja Grafindo Persada.

Nasution. 2006. Asas-asas Kurikulum. Jakarta : Bumi Aksara.

Riduwan. 2008. Skala Pengukuran Variabel-variabel Penelitian. Bandung: Alfabeta.

Sugiyono. 2007. Metode Penelitian Pendidikan (Pendekatan Kuantitatif, Kualitatif dan $R \& D)$. Bandung : Alfabeta 